\title{
Shining the Spotlight on Child Sexual Abuse
}

\author{
Kathleen McPhillips *
}

*Correspondence: Kathleen.mcphillips@newcastle.edu.au

Earlier this year, the film Spotlight won the Academy Award (Oscars) for Best Picture and Best Original Screenplay. Spotlight tells the story of a group of journalists at The Boston Globe who break the story of the clerical abuse of hundreds of children by over 200 Catholic priests in the Boston area in 2002. It was the first major reporting of abuse by Catholic clerics in the US and shocked the nation, indeed the world, with the breadth of abuse and the silencing of victims and their families by the Church and their lawyers.

I saw the film in Australia at a local cinema in Newcastle, New South Wales. As a social researcher writing on the Catholic Church at the Royal Commission and the NSW Special Inquiry into Child Sexual Abuse, I wasn't surprised that I recognised in the small audience a number of survivors, families and supporters of victims and Catholic community members. I wasn't surprised that it was a small number; this is a difficult film to watch about a subject most people do not want to think about.

The Royal Commission into institutional child abuse was set up in 2013 after years of work by survivors and supporters to uncover abuse across institutions including the Catholic Church.

Despite knowing much of the literature in the field and having attended

(C) Copyright: The Authors. This article is issued under the terms of the Creative Commons Attribution NonCommercial Share Alike License, which permits use and redistribution of the work provided that the original author and source are credited, the work is not used for commercial purposes and that any derivative works are made available under the same license terms. many sessions at the Royal Commission, it came as a shock when the last screen shots listed the number of American cities affected by clerical abuse and cities around the world. The list runs into the hundreds and in Australia includes Newcastle, Wollongong, Adelaide, Ballarat and Melbourne. People around me gasped as we recognised Newcastle on the list: somehow seeing our small city on the big screen bought home the reality of this crisis. Clerical sexual abuse is not a small issue on the periphery of social maladjustment. It's a major crisis of institutional abuse of power that has affected millions of people across the globe.

The film does a great job in recounting the story of how the journalists bought clerical abuse to public attention. This may not have happened at all unless a new Editor - Marty Baron (Lieve Schreiber) - was appointed. He 
read a small article on a Catholic priest - John Geoghan - who had been abusing children but allowed by Cardinal Bernard Law to continue working with children in parishes and schools. Baron directs the Spotlight team to investigate what Cardinal Law knew and how many priests and victims are involved. Despite missing documents, recalcitrant Church lawyers and Church silence, the team eventually uncovers over 200 abusive priests and a Church hierarchy who were systematically moving them between parishes and schools, setting up treatment centres in local neighbourhoods and paying victims paltry amounts of compensation and binding them to silence.

The journalists are not the real heroes. Five years prior to the publication of the story, the head of the Spotlight team Walter Robinson (Michael Keaton), had been handed legal files on victim cases by a lawyer working for the victims Mitchell Garabedian (Stanley Tucci) and a box of evidence from Phil Saviano (Neal Huff) who was representing SNAP (Survivors Network of those Abused by Priests). This material named paedophile priests and outed Cardinal Law for knowing about it but doing nothing. From this Robinson filed a small report which he deemed inconsequential at the back of paper. It took two outsiders - Baron who was from out of town and Jewish, and Garabedian, an Armenian - to see the seriousness of the issue.

Why did this happen? The answer to that lies in the dominance of the Catholic Church in the Boston area and the ways in which institutions create forms of social 'reality'. In a way, most of the journalists who were raised Catholic, were blind to the issue; they were insiders reporting on inside matters. And those matters did not look unusual or important. Compare that with journalists such as the award winning Joanne McCarthy, who broke the stories of Catholic clerical sexual abuse in the Newcastle-Maitland diocese over the last 10 years and who has repeatedly indicated that although she was raised Catholic she is now an atheist and has no ties to the Church. We can also see this in operation in the Royal Commission which is completely independent of any of the offending institutions.

Another important factor is the commonly held notion, especially by Church leaders, that sexual abuse is the result of 'a few bad apples' as has been noted by numerous Catholic clerics here. When bishop Paul Bird gave evidence at the first hearing into clerical abuse in Ballarat in May 2015 he indicated that the problem for the Church was not a systematic one, but of a small group of opportunistic men joining the priesthood for the wrong reasons. Likewise when Cardinal George Pell gave evidence in February 2016 by video link from Rome he said that he was aware that some boys had been abused but didn't think it was his responsibility to address this further. These beliefs do significant damage as they fail to recognize the 
problems that institutional cultures generate. To take a quote from Spotlight "It takes a village a raise a child, and a village to abuse a child". There are prickly moral issues involved in coming to terms with how so many societies across the globe have failed to protect children from harm. How have so many people known but done nothing? What does this say about the ways in which we treat those who are situated as different and other?

The real heroes in this appalling travesty of justice are the victims and survivors, their families and supporters. They are the ones who suffered the abuse and its aftermath. It was their stories which were disbelieved and discredited. They were often treated abysmally by the institution, and stigmatised as troublemakers. They are the ones who year after year have borne the psychological, social and financial consequences of major trauma yet who have continued to raise this issue until it is heard. The Royal Commission is Australia's chance to right this terrible wrong. If you can, see Spotlight, it at least shows how one community came to be outraged at what happened to their children.

To cite this article:

McPhillips, K. (2016). Shining the Spotlight on Child Sexual Abuse. Feminist Dissent, (1), 136-138. Retrieved from:

http://journals.warwick.ac.uk/index.php/feministdissent/article/view/15 